\title{
Nitrogen removal performance of anaerobic ammonia oxidation (ANAMMOX) in presence of organic matter
}

\author{
Weiqiang Zhu $\cdot$ Peiyu Zhang $\cdot$ Deshuang Yu $\cdot$ Huiyu Dong $\cdot$ Jin Li
}

Received: 8 August 2016/Accepted: 3 February 2017/Published online: 9 February 2017

(C) Springer Science+Business Media Dordrecht 2017

\begin{abstract}
A sequencing batch reactor (SBR) was used to test the nitrogen removal performance of anaerobic ammonium oxidation (ANAMMOX) in presence of organic matter. Mesophilic operation $\left(30 \pm 0.5^{\circ} \mathrm{C}\right)$ was performed with influent $\mathrm{pH}$ 7.5. The results showed, independent of organic matter species, ANAMMOX reaction was promoted when COD was lower than $80 \mathrm{mg} / \mathrm{L}$. However, specific ANAMMOX activity decreased with increasing organic matter content. Ammonium removal efficiency decreased to $80 \%$ when COD of sodium succinate, sodium potassium tartrate, peptone and lactose were 192.5, 210, 225 and $325 \mathrm{mg} / \mathrm{L}$, respectively. The stoichiometry ratio resulting from different OM differed largely and $\mathrm{R}_{1}$ could be as an indicator for $\mathrm{OM}$ inhibition. When COD concentration was $240 \mathrm{mg} / \mathrm{L}$, the loss of SAA resulting from lactose, peptone, sodium potassium tartrate and sodium
\end{abstract}

Electronic supplementary material The online version of this article (doi:10.1007/s10532-017-9785-x) contains supplementary material, which is available to authorized users.

W. Zhu $\cdot$ P. Zhang $\cdot$ D. Yu $\cdot$ J. Li (ه)

School of Environmental Science and Engineering, Qingdao University, Qingdao 266071, China

e-mail: 1jin0532@126.com

H. Dong

Key Laboratory of Drinking Water Science and Technology, Research Center for Eco-environmental Sciences, University of Chinese Academy of Sciences, Chinese Academy of Sciences, Beijing 100085, China succinate were $28,36,50$ and $55 \%$, respectively. Sodium succinate had the highest inhibitory effect on SAA. When ANAMMOX process was used to treat wastewater containing $\mathrm{OM}$, the modified Logistic model could be employed to predict the $\mathrm{NRE}_{\max }$.

Keywords Nitrogen removal - Organic matter · ANAMMOX · Denitrification · Kinetic model

\section{Introduction}

Over the last decades, nitrogen removal from sewage has gained wide concerns owing to its fatal nature to wildlife and causing eutrophication. Autotrophic nitrogen removal process is promising in sewage treatment. There are photoautotrophic system (Regmi et al. 2015), autotrophic denitrification (Liu et al. 2015) and anaerobic ammonium oxidation (ANAMMOX) reaction (Strous et al. 1998). Among these autotrophic reactions, ANAMMOX was regarded as an efficient process for nitrogen removal. In ANAMMOX process, $\mathrm{NH}_{4}{ }^{+}-\mathrm{N}$ was oxidized to $\mathrm{N}_{2}$ with $\mathrm{NO}_{2}{ }^{-}-\mathrm{N}$ as electron acceptor, which was devoted to treating $\mathrm{NH}_{4}{ }^{+}-\mathrm{N}$ rich wastewater. Although many advantages of ANAMMOX made it popular in wastewater treatment (Okamoto et al. 2012; Qiao et al. 2009), it still faced some problems such as inhibitory effect resulting from organic matter $(\mathrm{OM})$.

OM were unfavorable to ANAMMOX process, however, previous studies indicated that anaerobic 
ammonia oxidizing bacteria (AAOB) were still able to dominate the reactor with OM (Dapena-Mora and Campos 2007; Fernández et al. 2009; Kartal et al. 2007). ANAMMOX was successfully applied to sewage treatment with low $\mathrm{C} / \mathrm{N}$ (Vlaeminck et al. 2010; Yamamoto et al. 2008). However, when $\mathrm{C} / \mathrm{N}$ was higher than 1.0, AAOB could not compete with heterotrophic denitrifying bacteria (HDB) (Guven et al. 2005). Besides, Xu et al. (2009) stated that AAOB had advantages over HDB when treating sewage with low $\mathrm{C} / \mathrm{N}$. It reported that the activity of AAOB was completely inhibited with 3-4 mM methanol (Jensen et al. 2007). However, Isaka et al. (2008) came to the different conclusion that methanol only inhibited $71 \%$ of the AAOB activity when the concentration was $5 \mathrm{mM}$. In addition, Guven et al. (2005) revealed that low methanol concentrations led to complete, immediate and irreversible inhibition on ANAMMOX reaction. For acetate, Dapena-Mora and Campos (2007) reported $50 \mathrm{mM}$ acetate resulted in $70 \%$ inhibition on ANAMMOX. However, Guven et al. (2005) found that acetate was potentially substrate for AAOB. Phenol, chloramphenicol, penicillin, antibiotics and propionate had been studied, too (Fernández et al. 2009; Guven et al. 2005; Toh et al. 2002; van de Graaf et al. 1996). However, effects of various OMs on ANAMMOX were diverse, and inhibitory threshold values differed largely even for the same OM.

In this work, a sequencing batch reactor (SBR) was used to study the nitrogen removal performance of ANAMMOX in presence of OM. Specific ANAMMOX activity (SAA) was analyzed throughout the process. In addition, kinetic and thermodynamic analyses were performed to study inhibitory characteristics.

\section{Materials and methods}

\section{Experimental set-up}

Five parallel SBRs made of polymethyl methacrylate were used in this work. The reactors were doublejacketed with an effective volume of $1.5 \mathrm{~L}$. Operating temperature was kept at $35{ }^{\circ} \mathrm{C}$. All the reactors were covered with aluminum caps to prevent light. Hydraulic retention time (HRT) was $8 \mathrm{~h}$. During the experiment, reactors were stirred at $100 \mathrm{rpm} . \mathrm{N}_{2}(99.99 \%)$ was purged in influent to removal $\mathrm{O}_{2}$. The influent was pumped into reactors through peristaltic pump and influent $\mathrm{pH}$ was around 7.5 by adding $0.1 \mathrm{~mol} / \mathrm{L}$ hydrochloric acid or sodium hydroxide.

Inoculated sludge and synthetic wastewater

Each reactor was inoculated with $1 \mathrm{~L}$ ANAMMOX sludge which was obtained from two lab-scale reactors (with an effective volume of $7 \mathrm{~L}$ ) operated steadily over one year at $35 \pm 1{ }^{\circ} \mathrm{C}$. The inoculating sludge was mixed and added to each reactor. The sludge was brightly red with good settling property (presented in Fig. S1) and the concentration of it was $1500 \mathrm{mg} / \mathrm{L}$. The diameter of the granular sludge was $0.5-5.0 \mathrm{~mm}$, with a mean value of $1.72 \mathrm{~mm}$. Influent $\mathrm{NH}_{4}{ }^{+}-\mathrm{N}$ and $\mathrm{NO}_{2}{ }^{-}-\mathrm{N}$ were 80 and $105 \mathrm{mg} / \mathrm{L}$, respectively. The removal efficiencies of both substrates were higher than $98 \%$. Composition of synthetic wastewater was $(\mathrm{g} / \mathrm{L}): \mathrm{KH}_{2}$ $\mathrm{PO}_{4}$ 0.028; $\mathrm{CaCl}_{2}$ 0.14; $\mathrm{KHCO}_{3} 2.0 ; \mathrm{MgSO}_{4} \cdot 7 \mathrm{H}_{2} \mathrm{O} 0.2$; $\mathrm{NH}_{4} \mathrm{Cl}$ 0.336; $\mathrm{NaNO}_{2}$ 0.573. Trace element solutions I and II ( $1.2 \mathrm{ml} / \mathrm{L})$ were also added according to previous report (van de Graaf et al. 1995).

\section{Experimental procedures}

Lactose, peptone, sodium potassium tartrate and sodium succinate were added into the synthetic wastewater as influent. The control one started with inoculation of ANAMMOX sludge without any OM addition. The effect resulting from OM on ANAMMOX was studied simultaneously. The influent COD gradually increased from $40 \mathrm{mg} / \mathrm{L}$ to the concentration which caused ANAMMOX inhibition. And the inhibition threshold of COD was defined when $\mathrm{NH}_{4}{ }^{+}-\mathrm{N}$ removal efficiency decreased to $80 \%$ (Molinuevo et al. 2009; Ni et al. 2012). OM concentration was based on COD and six cycles were operated in each $\mathrm{OM}$ concentration.

Kinetic evaluation

The modified Logistic model and modified Boltzmann model (Yang and Jin 2013) were employed to quantify the nitrogen removal characteristics of ANAMMOX performance in a cycle.

$$
\mathrm{H}=\frac{\mathrm{H}_{\max }}{1+\exp \left[4 \times \mathrm{R}_{\mathrm{m}} \times(\lambda-\mathrm{t}) / \mathrm{H}_{\max }+2\right]}
$$


$\mathrm{H}=\mathrm{H}_{\max }+\frac{\mathrm{H}_{\min }-\mathrm{H}_{\max }}{1+\exp \left[\left(\mathrm{t}-\mathrm{t}_{\mathrm{c}}\right) / \mathrm{t}_{\mathrm{d}}\right]}$

where $\mathrm{R}_{\mathrm{m}}$ represents maximum nitrogen removal rate $(\% / \mathrm{h}) ; \lambda$ represents lag time $(\mathrm{h}) ; \mathrm{t}$ represents operating time $(h) ; t_{c}$ represents center value $(h) ; t_{d}$ represents time constant (h). When Eqs. 1 and 2 were used to demonstrate the progress of substrate degradation in batch tests, $H$ (NRE, nitrogen removal efficiency) and $\mathrm{H}_{\max }\left(\mathrm{NRE}_{\max }\right.$, maximum nitrogen removal efficiency) describe the cumulative degraded substrate value and maximum degraded substrate value, respectively (Wang and Wan 2009).

Analytical methods

The influent and effluent samples were collected each day and then analyzed immediately. $\mathrm{NH}_{4}{ }^{+}-\mathrm{N}, \mathrm{NO}_{2}{ }^{-}$$\mathrm{N}$ and $\mathrm{NO}_{3}{ }^{-}-\mathrm{N}$ concentrations were measured with the Nessler's reagent spectrophotometry method, ultraviolet spectrophotometric screening method and N-(1naphthyl)-ethylenedia-mine spectrophotometric method, respectively (APHA 1998). Sludge concentration, COD and TN were all analyzed according to the standard methods (APHA 1998). Temperature and $\mathrm{pH}$ were measured by the WTW 340i/SET pH/Oxi portable multi-parameter measuring meter. Each analytical result reported in this work was analyzed in triplicate. The activity inhibition was described as Eq. 3.

$\mathrm{C}_{\mathrm{I}}=\left(\mathrm{SAA}-\mathrm{SAA}_{\mathrm{c}}\right) / \mathrm{SAA}_{\mathrm{c}}$

$\Delta_{\mathrm{r}} \mathrm{G}_{\mathrm{m}}^{\prime}=\Delta_{\mathrm{r}} \mathrm{G}_{\mathrm{m}}^{\theta}+\mathrm{RT} \cdot \ln \mathrm{Q}_{\mathrm{a}}$

where $C_{I}$ represents inhibition degree; SAA represents specific ANAMMOX activity, $\mathrm{SAA}_{\mathrm{c}}$ represents SAA in control group; $\Delta_{\mathrm{r}} \mathrm{G}_{\mathrm{m}}^{\theta}$ represents standard Gibbs free energy; $\mathrm{R}$ represents ideal gas constant and its value is $8.314 \mathrm{~J} / \mathrm{kg} / \mathrm{K}$; T represents Kelvin.

Completely closed vials were used to perform SAA batch assays. The influent $\mathrm{NH}_{4}{ }^{+}-\mathrm{N}$ and $\mathrm{NO}_{2}{ }^{-}-\mathrm{N}$ concentrations were 80 and $105 \mathrm{mg} / \mathrm{L}$, respectively. The sludge concentration was $1500 \mathrm{mg} / \mathrm{L}$. The influent $\mathrm{pH}$ value was 7.5 and the temperature was maintained at $35^{\circ} \mathrm{C}$. $\mathrm{N}_{2}$ was purged into vials to remove $\mathrm{O}_{2}$. $\mathrm{NH}_{4}{ }^{+}-\mathrm{N}$ and $\mathrm{NO}_{2}{ }^{-}-\mathrm{N}$ were determined at regular intervals $(0.5 \mathrm{~h})$. Eventually, SAA was calculated by the ratio of maximum substrate consumption rate to sludge concentration (Qiao et al. 2014).

\section{Results and discussion}

Nitrogen removal performance of ANAMMOX process

Nitrogen removal performances of ANAMMOX processes with different OMs were presented in Fig. 1. When lactose was added, effluent $\mathrm{NH}_{4}{ }^{+}-\mathrm{N}$ and $\mathrm{NO}_{2}{ }^{-}-$ $\mathrm{N}$ varied little at COD $\leq 160 \mathrm{mg} / \mathrm{L}$. With $360 \mathrm{mg} / \mathrm{L}$ COD, effluent $\mathrm{NH}_{4}{ }^{+}-\mathrm{N}$ increased to $20 \pm 2 \mathrm{mg} / \mathrm{L}$ while ARE and ammonia removal rate (ARR) ARR were $75 \pm 3 \%$ and $0.175 \pm 0.01 \mathrm{~kg} /\left(\mathrm{m}^{3}\right.$ day $)$, respectively. In addition, effluent $\mathrm{NO}_{3}{ }^{-} \mathrm{N}$ was lower than that in influent. The maximum NRE and nitrogen removal rate (NRR) reached $94.5 \pm 1 \%$ and $0.535 \pm$ $0.01 \mathrm{~kg} /\left(\mathrm{m}^{3}\right.$ day $)$, respectively, with $280 \mathrm{mg} / \mathrm{L}$ COD. When peptone was added, effluent $\mathrm{NH}_{4}{ }^{+}-\mathrm{N}$ was $18 \pm 2 \mathrm{mg} / \mathrm{L}$ with $240 \mathrm{mg} / \mathrm{L}$ COD. ARE and ARR were $77.5 \pm 2.5 \%$ and $0.188 \pm 0.01 \mathrm{~kg} /\left(\mathrm{m}^{3}\right.$ day $)$, respectively. NRE and NRR peaked at $87 \pm 1 \%$ and $0.50 \pm 0.005 \mathrm{~kg} /\left(\mathrm{m}^{3}\right.$ day $)$ with $160 \mathrm{mg} / \mathrm{L} \mathrm{COD}$ and then decreased to $81.5 \pm 1.5 \%$ and $0.485 \pm 0.01 \mathrm{~kg} /$ $\left(\mathrm{m}^{3}\right.$ day), respectively. When sodium potassium tartrate was added, effluent $\mathrm{NH}_{4}{ }^{+}-\mathrm{N}$ and $\mathrm{NO}_{2}{ }^{-}-\mathrm{N}$ varied little with $\mathrm{COD} \leq 120 \mathrm{mg} / \mathrm{L}$. When $\mathrm{COD}$ was $240 \mathrm{mg} / \mathrm{L}$, effluent $\mathrm{NH}_{4}{ }^{+}-\mathrm{N}$ increased to $21 \pm 2 \mathrm{mg} /$ $\mathrm{L}$ and ARE and ARR were $71.5 \pm 2.5 \%$ and $0.177 \pm 0.012 \mathrm{~kg} /\left(\mathrm{m}^{3}\right.$ day $)$, respectively. The maximum NRE and nitrogen removal rate (NRR) reached $87 \pm 1 \%$ and $0.485 \pm 0.005 \mathrm{~kg} /\left(\mathrm{m}^{3}\right.$ day $)$, and then decreased to $83 \pm 1 \%$ and $0.455 \pm 0.02 \mathrm{~kg} /\left(\mathrm{m}^{3}\right.$ day $)$. When sodium succinate was added, effluent $\mathrm{NH}_{4}{ }^{+}-\mathrm{N}$ increased when COD was more than $120 \mathrm{mg} / \mathrm{L}$. NRE decreased from $83 \pm 1$ to $77.5 \pm 2 \%$. All were lower than the control group, which indicated the inhibition effect throughout the whole process.

Low OM content did not affect ANAMMOX greatly. However, high OM concentration would apparently inhibit the ANAMMOX process. The inhibition threshold values of lactose, peptone, sodium potassium tartrate and sodium succinate were 325 , 240, 210 and $192.5 \mathrm{mg} / \mathrm{L}$. The inhibitory effect resulting from different $\mathrm{OMs}$ varied. AAOB had more affinity to micro-molecular OMs than macro-molecular ones. With OM added, nitrogen was removed through competition between ANAMMOX and denitrification (Anjali and Sabumon 2014; Ma et al. 2016). At low OM concentration, AAOB could coexist with HDB. However, at high OM concentration, 

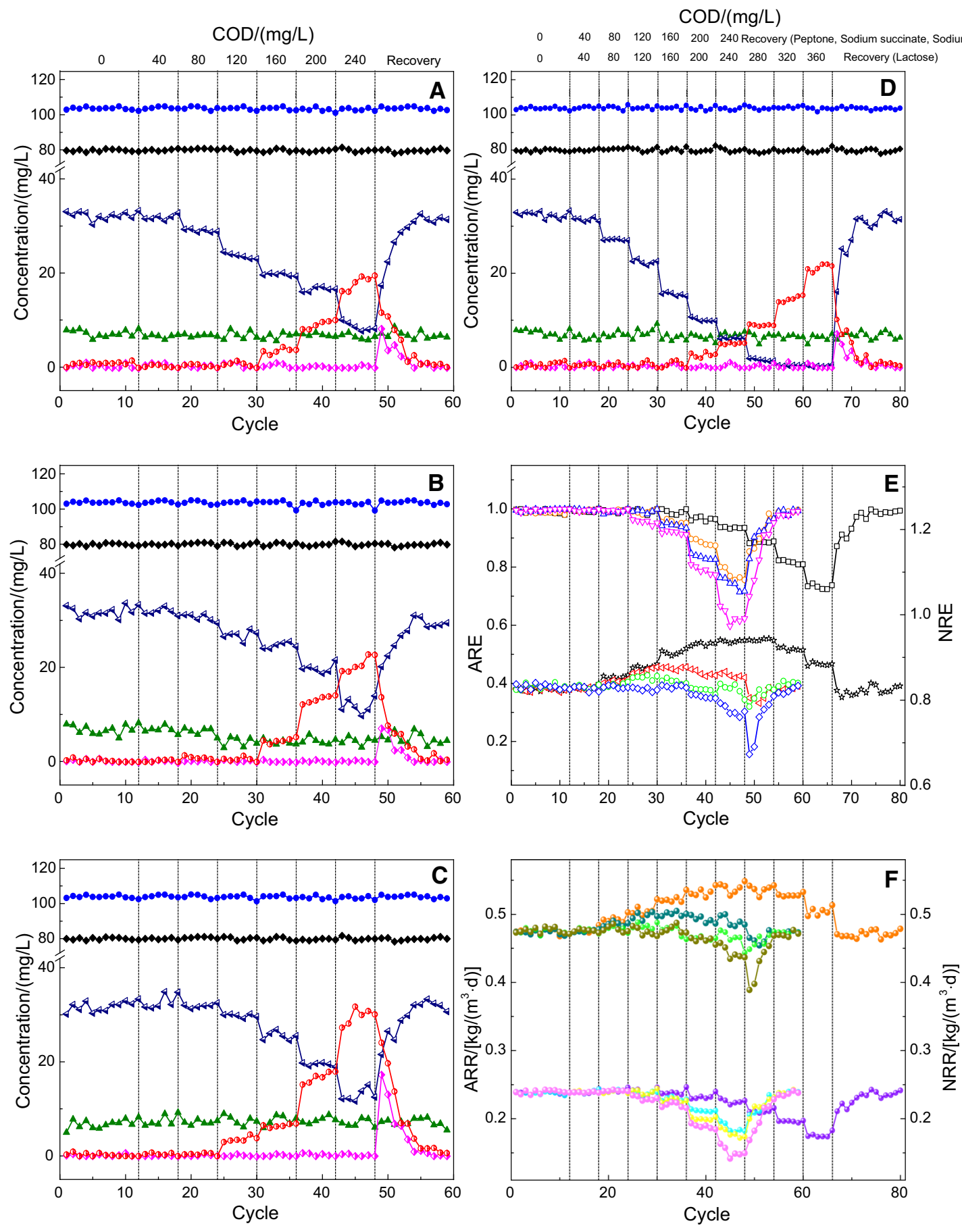

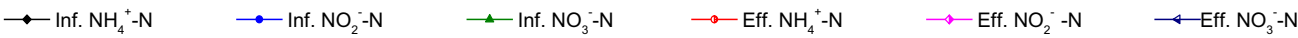

$$
\begin{aligned}
& \longrightarrow \text { Lactose (ARE) } \multimap \text { Peptone (ARE) } \longrightarrow \text { Sodium potassium tartrate (ARE) } \longrightarrow \text { Sodium succinate (ARE) } \\
& \longrightarrow \text { - Lactose (NRE) } \backsim \text {-Peptone (NRE) } \multimap-\text { Sodium potassium tartrate (NRE) } \multimap \text { Sodium succinate (NRE) } \\
& \multimap \text { Lactose (ARR) } \quad-\text { Peptone (ARR) } \quad \text { Sodium potassium tartrate (ARR) } \because \text { Sodium succinate (ARR) } \\
& \multimap \text { Lactose (NRR) } \multimap \text { Peptone (NRR) —-Sodium potassium tartrate (NRR) } \multimap \text { Sodium succinate (NRR) }
\end{aligned}
$$

Fig. 1 Nitrogen removal performance of ANAMMOX process in presence of OM: a peptone; $\mathbf{b}$ sodium potassium tartrate; $\mathbf{c}$ sodium succinate; $\mathbf{d}$ lactose; e removal efficiency of $\mathrm{NH}_{4}{ }^{+}-\mathrm{N}$ and $\mathrm{TN}$; $\mathbf{f}$ removal rate of $\mathrm{NH}_{4}{ }^{+}-\mathrm{N}$ and $\mathrm{TN}$ 
increasing $\mathrm{HDB}$ competed for $\mathrm{NO}_{2}{ }^{-}-\mathrm{N}$ with AAOB. Our results agreed with Chamchoi et al. (2008) that HDB could rapidly grow with high COD concentration $(300 \mathrm{mg} / \mathrm{L})$ and adversely affect AAOB. Comparison of inhibition in presence of various OMs was presented in Table 1. Independent of OM species, in general, it was the same that ANAMMOX reaction was inhibited when high OM concentration was added.

When OM was removed from the reactor in the last period of research, ANAMMOX activities in all SBRs recovered in 8 days. $\mathrm{NH}_{4}{ }^{+}-\mathrm{N}$ and $\mathrm{NO}_{2}{ }^{-}-\mathrm{N}$ were completely removed. The value of ARR and NRR were back to $0.23 \pm 0.008$ and $0.47 \pm 0.012 \mathrm{~kg} /$

Table 1 Comparison of inhibition in presence of various OM

\begin{tabular}{|c|c|c|c|c|}
\hline OMs & Operation mode & Concentration & Effect & References \\
\hline Non-fat dry milk & Continuous, UASB & $308 \mathrm{mg} / \mathrm{L}$ & $-20 \%$ & Ni et al. (2012) \\
\hline $\begin{array}{l}\text { Pig manure effluent (after UASB-post- } \\
\text { digestion) }\end{array}$ & $\begin{array}{l}\text { Semi-continuous, } \\
\text { UASB }\end{array}$ & $\begin{array}{l}\text { Higher than } \\
237 \mathrm{mg} / \mathrm{L}^{1}\end{array}$ & $-100 \%$ & Molinuevo et al. (2009) \\
\hline $\begin{array}{l}\text { Pig manure effluent (after UASB-post- } \\
\text { digestion) }\end{array}$ & $\begin{array}{l}\text { Semi-continuous, } \\
\text { UASB }\end{array}$ & $\begin{array}{l}\text { Higher than } \\
290 \mathrm{mg} / \mathrm{L}^{\mathrm{a}}\end{array}$ & $-100 \%$ & Molinuevo et al. (2009) \\
\hline Glucose & Continuous, UASB & $100 \mathrm{mg} / \mathrm{L}$ & $\begin{array}{l}\text { Lower than } \\
-10 \%^{\mathrm{a}}\end{array}$ & Yuan et al. (2015) \\
\hline Glucose & Continuous, UASB & $300 \mathrm{mg} / \mathrm{L}$ & $-31 \%$ & Yuan et al. (2015) \\
\hline Glucose & Batch, Vials & $1 \mathrm{mM}$ & $5 \%$ & Oshiki et al. (2011) \\
\hline Methanol & Continuous $^{3}$ & $0.5 \mathrm{mM}$ & $-100 \%$ & Guven et al. (2005) \\
\hline Methanol & Batch, Vials & $1 \mathrm{mM}$ & $-86 \%$ & Oshiki et al. (2011) \\
\hline Methanol & Batch & $1.7 \mathrm{mM}$ & $-30 \%$ & Isaka et al. (2008) \\
\hline Methanol & Batch & $3.3 \mathrm{mM}$ & $-49 \%$ & Isaka et al. (2008) \\
\hline Methanol & Batch & $5 \mathrm{mM}$ & $-71 \%$ & Isaka et al. (2008) \\
\hline Ethanol & Batch, Vials & $1 \mathrm{mM}$ & $-91 \%$ & Oshiki et al. (2011) \\
\hline Ethanol & $\mathrm{Batch}^{3}$ & $1.1 \mathrm{mM}$ & $-3 \%$ & Isaka et al. (2008) \\
\hline Ethanol & $\mathrm{Batch}^{3}$ & $3.3 \mathrm{mM}$ & $-10 \%$ & Isaka et al. (2008) \\
\hline Ethanol & Continuous $^{3}$ & $2 \mathrm{mM}$ & $-30 \%$ & Guven et al. (2005) \\
\hline Acetate & Batch $^{3}$ & $10 \mathrm{mM}$ & $\begin{array}{l}\text { No significant } \\
\text { effect }\end{array}$ & $\begin{array}{l}\text { Dapena-Mora and Campos } \\
\text { (2007) }\end{array}$ \\
\hline Acetate & Batch, Vials & $1 \mathrm{mM}$ & $-2 \%$ & Oshiki et al. (2011) \\
\hline Acetate & Batch, Vials & $10 \mathrm{mM}$ & $\begin{array}{l}\text { No significant } \\
\text { effect }\end{array}$ & $\begin{array}{l}\text { Dapena-Mora and Campos } \\
\text { (2007) }\end{array}$ \\
\hline Acetate & Batch, Vials & $25 \mathrm{mM}$ & $-22 \%$ & $\begin{array}{l}\text { Dapena-Mora and Campos } \\
\text { (2007) }\end{array}$ \\
\hline Acetate & Batch, Vials & $50 \mathrm{mM}$ & $-70 \%$ & $\begin{array}{l}\text { Dapena-Mora and Campos } \\
\text { (2007) }\end{array}$ \\
\hline Sucrose & Continuous, UASB & $700 \mathrm{mg} / \mathrm{L}$ & $-45 \%$ & Tang et al. (2010) \\
\hline Propionate & Batch, Vials & $1 \mathrm{mM}$ & $-1 \%$ & Oshiki et al. (2011) \\
\hline Formate & Batch, Vials & $1 \mathrm{mM}$ & $-36 \%$ & Oshiki et al. (2011) \\
\hline Tetracycline hydrochloride & Continuous & $10 \mathrm{mg} / \mathrm{L}$ & $-60 \%$ & Fernández et al. (2009) \\
\hline Chloramphenicol & Batch & $200 \mathrm{mg} / \mathrm{L}$ & $-68 \%$ & van de Graaf et al. (1995) \\
\hline Lactose & Batch, SBR & $360 \mathrm{mg} / \mathrm{L}$ & $-26 \%$ & This study \\
\hline Peptone & Batch, SBR & $240 \mathrm{mg} / \mathrm{L}$ & $-25.5 \%$ & This study \\
\hline Sodium potassium tartrate & Batch, SBR & $240 \mathrm{mg} / \mathrm{L}$ & $-28 \%$ & This study \\
\hline Sodium succinate & Batch, SBR & $240 \mathrm{mg} / \mathrm{L}$ & $-38 \%$ & This study \\
\hline
\end{tabular}

${ }^{a}$ When the COD was higher than that concentration, the results were all suitable 
( $\mathrm{m}^{3}$ day). These results revealed that $\mathrm{OM}$ inhibition on ANAMMOX was reversible. Besides, HDB did not exist in reactor due to absence of carbon source, and the competition for $\mathrm{NO}_{2}{ }^{-} \mathrm{N}$ between $\mathrm{AAOB}$ and HDB disappeared. AAOB dominated the reactor again easily. The ability of AAOB to resist OM shock was good and ANAMMOX process could also be used to treat wastewater containing low OM content.

\section{Stoichiometry}

The stoichiometry can be used as evidence for ANAMMOX inhibition (Sun et al. 2011). The variations of $\mathrm{R}_{1}$ (the ratio of consumed $\mathrm{NO}_{2}{ }^{-} \mathrm{N}$ to consumed $\mathrm{NH}_{4}{ }^{+}-\mathrm{N}$ ) and $\mathrm{R}_{2}$ (the ratio of produced $\mathrm{NO}_{3}{ }^{-}-\mathrm{N}$ to consumed $\mathrm{NH}_{4}{ }^{+}-\mathrm{N}$ ) with different $\mathrm{OM}$ were presented in Fig. 2. The $\mathrm{R}_{1}$ and $\mathrm{R}_{2}$ of control group were 1.29 and 0.315 , respectively. When $\mathrm{OM}$ was added, the $R_{1}$ varied little with COD $\leq 80 \mathrm{mg} / \mathrm{L}$. Independent of $\mathrm{OM}$ species, $\mathrm{R}_{1}$ increased with growing COD. When COD was no more than $40 \mathrm{mg} / \mathrm{L}, \mathrm{R}_{2}$ varied little. Then it increased with increasing COD. Our results agreed with previous report that both stoichiometric ratios deviated from theoretical values with increasing $\mathrm{COD}(\mathrm{Li}$ et al. 2016). It demonstrated that OM addition affected ANAMMOX process and heterotrophic denitrification occurred with high COD content. When OM was removed from the reactor, $R_{1}$ and $R_{2}$ became $1.30 \pm 0.03$ and $0.315 \pm 0.02$, respectively. ANAMMOX activity recovered quickly.

The stoichiometry ratio resulting from different OM differed largely. When COD was $240 \mathrm{mg} / \mathrm{L}$, the $\mathrm{R}_{1}$ of sodium succinate addition was the most of all. It was in line with previous result that the inhibitory effect of sodium succinate was the most of all. $\mathrm{R}_{1}$ could be as an indicator for OM inhibition. In addition, the change of $R_{1}$ was slower than $R_{2}$ with increasing COD. There were two possibilities leading to the phenomenon. Firstly, the metabolic pathways of
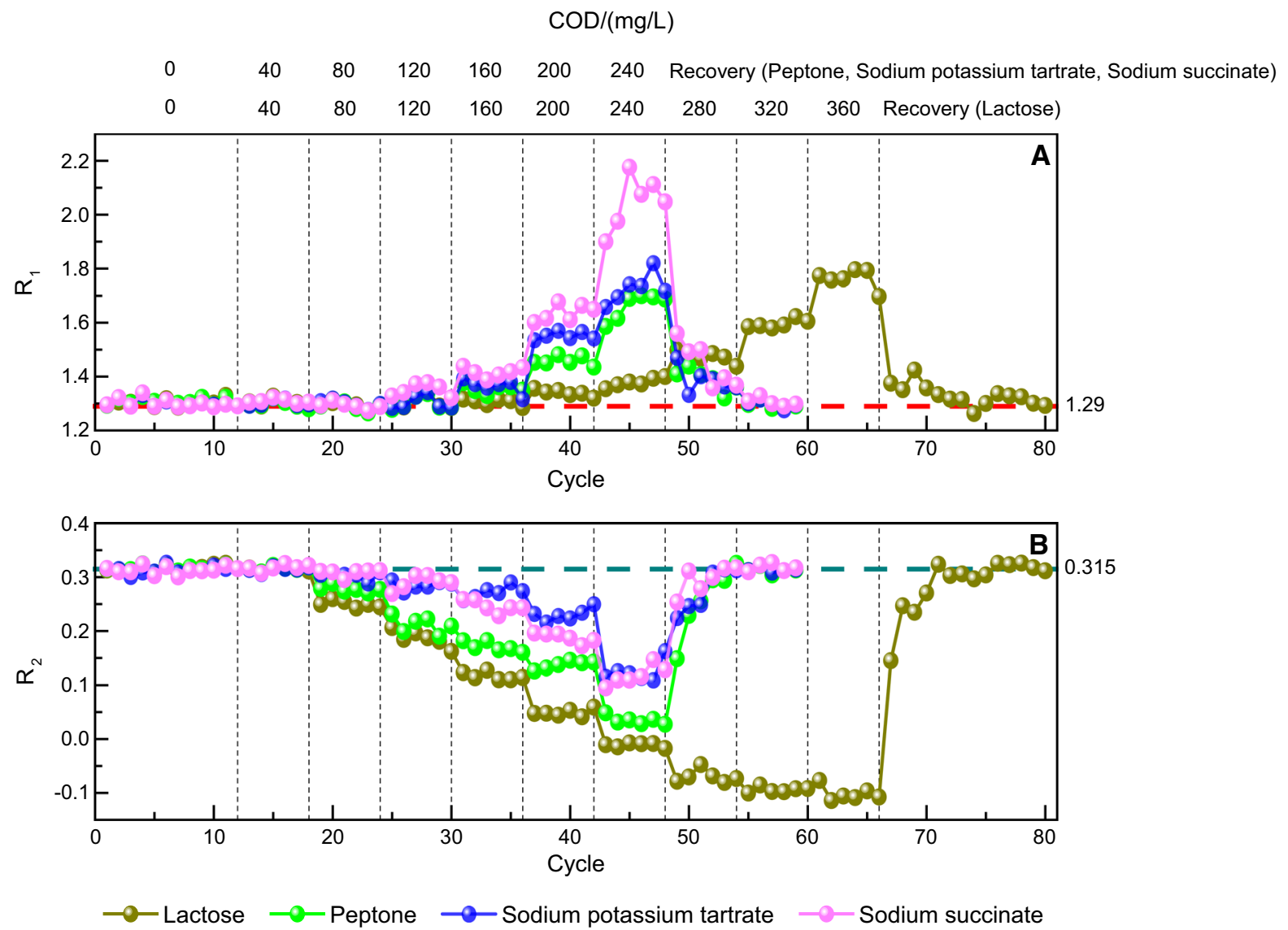

Fig. 2 Stoichiometric ratio in presence of $\mathrm{OM}$ 
AAOB might be transformed (Dalsgaard and Thamdrup 2002; Dosta et al. 2008). Secondly, other electron acceptor except $\mathrm{NO}_{2}{ }^{-}-\mathrm{N}$ might exist when $\mathrm{OM}$ was added.

Previous study indicated that, as the result of fast growth rate and cell yield of HDB, AAOB could lose their activity or even vanish from the reactor when OM was added (Kuenen 2008). Tomar et al. (2015) reported that $\mathrm{HDB}$ had higher affinity to $\mathrm{NO}_{2}{ }^{-} \mathrm{N}$ than AAOB. HDB could outcompete AAOB when $\mathrm{OM}$ content was high. Both resulted in the increase of $\mathrm{R}_{1}$ and decrease of $\mathrm{R}_{2}$. Comparison of stoichiometric ratios with various OM was presented in Table 2 . Independent of OM species, in general, it was the same that $R_{1}$ increased and $R_{2}$ decreased when $O M$ was added.

\section{Activity of AAOB}

Batch test was conducted to determine SAA in presence of OM. The results were presented Fig. 3. When peptone was added, SAA increased with COD no more than $100 \mathrm{mg} / \mathrm{L}$. Then it decreased to $0.22 \mathrm{kgNH}_{4}{ }^{+}-\mathrm{N} / \mathrm{kgVSS}$ day with $240 \mathrm{mg} / \mathrm{L}$ COD. Similar results were found when lactose or sodium potassium tartrate was added. SAA increased with COD no more than $40 \mathrm{mg} / \mathrm{L}$, and then decreased with increasing COD. However, when sodium succinate

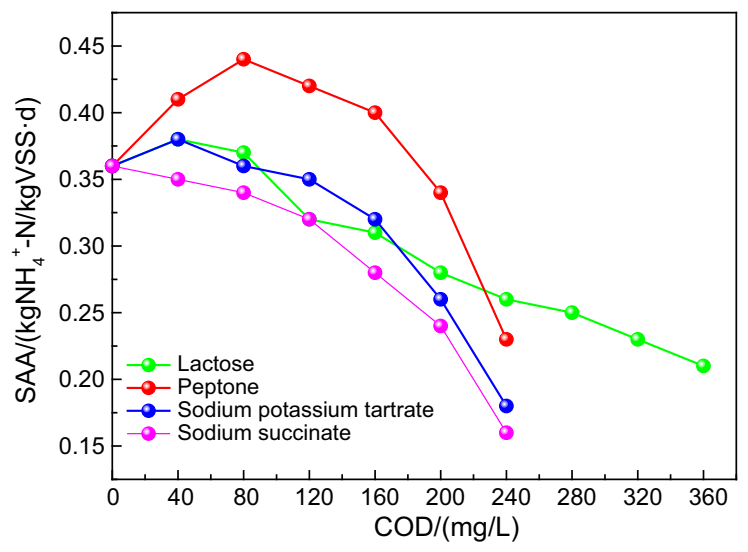

Fig. 3 Variations of SAA with COD in presence of OM

Table 2 Comparison of stoichiometric ratio in presence of OM

\begin{tabular}{|c|c|c|c|c|c|c|}
\hline \multirow[t]{2}{*}{$\mathrm{OM}$} & \multicolumn{2}{|c|}{ Control group } & \multirow{2}{*}{$\begin{array}{l}\text { Concentration } \\
(\mathrm{mg} / \mathrm{L})\end{array}$} & \multicolumn{2}{|c|}{ Experimental result } & \multirow[t]{2}{*}{ Reference } \\
\hline & $\mathrm{R}_{1}$ & $\mathrm{R}_{2}$ & & $\mathrm{R}_{1}$ & $\mathrm{R}_{2}$ & \\
\hline Propionate & 1.30 & - & 296 & 1.60 & - & Guven et al. (2005) \\
\hline Non-fat dry milk & 1.01 & 0.18 & 100 & 1.04 & 0.12 & Ni et al. (2012) \\
\hline Non-fat dry milk & 1.01 & 0.18 & 200 & 1.10 & - & Ni et al. (2012) \\
\hline Non-fat dry milk & 1.01 & 0.18 & 400 & 1.39 & 0.06 & (Ni et al. 2012) \\
\hline Glucose & $1.29 \pm 0.09$ & $0.26 \pm 0.03$ & 100 & $1.33 \pm 0.10$ & $0.24 \pm 0.03$ & Tang et al. (2013) \\
\hline Glucose & $1.29 \pm 0.09$ & $0.26 \pm 0.03$ & 400 & $1.39 \pm 0.12$ & $0.05 \pm 0.02$ & (Tang et al. 2013) \\
\hline Glucose & $1.29 \pm 0.09$ & $0.26 \pm 0.03$ & 800 & $4-5$ & - & Tang et al. (2013) \\
\hline UASB-post-digested effluent & 1.32 & - & 95 & 1.49 & - & Molinuevo et al. (2009) \\
\hline UASB-post-digested effluent & 1.32 & - & 237 & 3.03 & - & Molinuevo et al. (2009) \\
\hline Lactose & 1.29 & 0.315 & 80 & 1.293 & 0.25 & This study \\
\hline Lactose & 1.29 & 0.315 & 240 & 1.40 & 0.02 & This study \\
\hline Lactose & 1.29 & 0.315 & 360 & 1.70 & -0.11 & This study \\
\hline Peptone & 1.29 & 0.315 & 80 & 1.295 & 0.27 & This study \\
\hline Peptone & 1.29 & 0.315 & 240 & 1.69 & 0.03 & This study \\
\hline Sodium potassium tartrate & 1.29 & 0.315 & 80 & 1.298 & 0.26 & This study \\
\hline Sodium potassium tartrate & 1.29 & 0.315 & 240 & 1.72 & 0.07 & This study \\
\hline Sodium succinate & 1.29 & 0.315 & 80 & 1.288 & 0.31 & This study \\
\hline Sodium succinate & 1.29 & 0.315 & 240 & 2.05 & 0.12 & This study \\
\hline
\end{tabular}


was added, SAA decreased with increasing COD throughout the whole process. Different OMs had different effects on ANAMMOX process. Activity of AAOB could be enhanced when some OMs were added (peptone, lactose and sodium potassium tartrate). However, independent of OM species, SAA decreased sharply when COD was high. This also agreed with previous report that SAA sharply decreased from $0.27 \mathrm{kgNH}_{4}{ }^{+}-\mathrm{N} / \mathrm{kgVSS}$ day without $\mathrm{OM}$ to $0.07 \mathrm{kgNH}_{4}{ }^{+}-\mathrm{N} / \mathrm{kgVSS}$ day with $700 \mathrm{mg} / \mathrm{L}$ COD (Tang et al. 2013).

Comparison of SAA with different OMs both in previous studies and this work was presented in Table 3. Inhibitory effects resulting from different OMs differed largely. In this work, SAA changed slowest when lactose was added. It indicated that lactose had little effect on ANAMMOX process. When COD concentration was $240 \mathrm{mg} / \mathrm{L}$, the loss of SAA resulting from lactose, peptone, sodium potassium tartrate and sodium succinate were $28,36,50$ and $55 \%$, respectively. Sodium succinate had the highest inhibitory effect on SAA. As a result, both the OM species and concentration affected the activity of AAOB.
Kinetic and thermodynamic analyses

The removal performance of $\mathrm{TN}$ was described by modified Logistic model and modified Boltzmann model. The results were presented in Tables 4 and 5 . $\mathrm{R}^{2}$ were all higher than 0.95 , which indicated that both models could simulate the process well in a typical operation. Compared to modified Boltzmann model, modified Logistic model described nitrogen removal performance better. Independent of OM species and concentration, $\mathrm{NRE}_{\max }$ values simulated from the model were quite similar with ones achieved from experiment. Besides, unlike the modified Boltzmann model, the modified Logistic model was a threeparameter model. It was simpler and easier to simulate experimental process and the solution of threeparameter model was more stable (Zwietering et al. 1990). When ANAMMOX process was used to treat wastewater containing $\mathrm{OM}$, the modified Logistic model could be employed to predict the $\mathrm{NRE}_{\max }$ very well.

When OM was added, heterotrophic denitrification reaction occurred in the reactor. The equations of ANAMMOX (van de Graaf et al. 1995), nitrite-based

Table 3 Comparison of SAA in presence of OM

\begin{tabular}{|c|c|c|c|c|c|}
\hline \multirow[t]{2}{*}{$\mathrm{OM}$} & \multicolumn{2}{|c|}{$\begin{array}{l}\text { Influent nitrogen } \\
\text { concentration }(\mathrm{mg} / \mathrm{L})\end{array}$} & \multirow[t]{2}{*}{$\begin{array}{l}\text { COD concentration } \\
(\mathrm{mg} / \mathrm{L})\end{array}$} & \multirow[t]{2}{*}{$\mathrm{SAA}\left(\mathrm{kg} \mathrm{NH}{ }_{4}^{+}-\mathrm{N} / \mathrm{kg}\right.$ VSS d) } & \multirow[t]{2}{*}{ References } \\
\hline & $\mathrm{NH}_{4}{ }^{+}-\mathrm{N}$ & $\mathrm{NO}_{2}{ }^{-}-\mathrm{N}$ & & & \\
\hline \multirow[t]{4}{*}{ Glucose } & $250-350$ & $320-430$ & 0 & 0.27 & \multirow[t]{4}{*}{ Tang et al. (2013) } \\
\hline & 350 & 430 & 200 & 0.24 & \\
\hline & 350 & 430 & 400 & 0.19 & \\
\hline & 350 & 430 & 800 & 0.07 & \\
\hline \multirow[t]{2}{*}{ Sucrose } & 240 & 240 & 0 & 0.317 & \multirow[t]{2}{*}{ Tang et al. (2010) } \\
\hline & 240 & 240 & Recover from 700 & 0.122 & \\
\hline \multirow[t]{2}{*}{ Chloramphenicol } & 150 & 150 & 0 & 0.25 & \multirow[t]{2}{*}{ Fernández et al. (2009) } \\
\hline & 150 & 150 & 20 & 0.05 & \\
\hline \multirow[t]{2}{*}{ Tetracycline hydrochloride } & 150 & 150 & 0 & 0.26 & \multirow[t]{2}{*}{ Fernández et al. (2009) } \\
\hline & 150 & 150 & 10 & 0.10 & \\
\hline Control group & 80 & 105 & 0 & 0.36 & This study \\
\hline Lactose & 80 & 105 & 360 & 0.21 & \\
\hline Peptone & 80 & 105 & 240 & 0.23 & \\
\hline Sodium potassium tartrate & 80 & 105 & 240 & 0.18 & \\
\hline Sodium succinate & 80 & 105 & 240 & 0.16 & \\
\hline
\end{tabular}


Table 4 Simulated values through the modified Logistic model

\begin{tabular}{|c|c|c|c|c|c|c|c|c|c|c|}
\hline Lactose & 0 & 40 & 80 & 120 & 160 & 200 & 240 & 280 & 320 & 360 \\
\hline $\mathrm{NRE}_{\max }(\%)$ & 82.64 & 83.71 & 85.74 & 88.57 & 91.84 & 93.05 & 92.99 & 93.30 & 91.42 & 89.28 \\
\hline $\mathrm{R}_{\max }(\% / \mathrm{h})$ & 25.02 & 26.76 & 26.24 & 25.00 & 27.22 & 27.91 & 27.48 & 26.65 & 26.74 & 26.36 \\
\hline$\lambda(\mathrm{h})$ & 1.00 & 1.05 & 0.97 & 0.80 & 0.87 & 0.86 & 0.90 & 0.91 & 0.86 & 0.74 \\
\hline $\mathrm{R}^{2}$ & 0.9947 & 0.9926 & 0.9948 & 0.9968 & 0.9947 & 0.9955 & 0.9967 & 0.9954 & 0.9953 & 0.9937 \\
\hline Peptone & 0 & 40 & 80 & 120 & 160 & 200 & 240 & & & \\
\hline $\mathrm{NRE}_{\max }(\%)$ & 82.64 & 82.53 & 84.73 & 86.26 & 87.29 & 83.23 & 83.18 & & & \\
\hline $\mathrm{R}_{\max }(\% / \mathrm{h})$ & 25.02 & 27.22 & 32.52 & 35.30 & 33.94 & 28.77 & 22.50 & & & \\
\hline$\lambda(\mathrm{h})$ & 1.00 & 0.77 & 0.83 & 0.91 & 1.10 & 0.65 & 0.89 & & & \\
\hline $\mathrm{R}^{2}$ & 0.9947 & 0.9922 & 0.9954 & 0.9965 & 0.9978 & 0.9950 & 0.9854 & & & \\
\hline Sodium potassium tartrate & 0 & 40 & 80 & 120 & 160 & 200 & 240 & & & \\
\hline $\mathrm{NRE}_{\max }(\%)$ & 82.64 & 82.98 & 84.42 & 86.77 & 84.10 & 82.12 & 79.27 & & & \\
\hline $\mathrm{R}_{\max }(\% / \mathrm{h})$ & 25.02 & 26.86 & 26.99 & 29.52 & 33.46 & 26.95 & 24.75 & & & \\
\hline$\lambda(\mathrm{h})$ & 1.00 & 0.76 & 0.87 & 0.90 & 1.00 & 0.60 & 0.65 & & & \\
\hline $\mathrm{R}^{2}$ & 0.9947 & 0.9952 & 0.9935 & 0.9968 & 0.9952 & 0.9951 & 0.9928 & & & \\
\hline \multicolumn{11}{|l|}{ Sodium succinate } \\
\hline $\mathrm{NRE}_{\max }(\%)$ & 82.64 & 81.87 & 82.77 & 82.93 & 81.59 & 80.21 & 75.91 & & & \\
\hline $\mathrm{R}_{\max }(\% / \mathrm{h})$ & 25.02 & 24.46 & 25.03 & 22.64 & 25.54 & 26.67 & 23.79 & & & \\
\hline$\lambda(\mathrm{h})$ & 1.00 & 0.87 & 0.78 & 0.56 & 0.64 & 0.65 & 0.62 & & & \\
\hline $\mathrm{R}^{2}$ & 0.9947 & 0.9942 & 0.9952 & 0.9876 & 0.9897 & 0.9943 & 0.9941 & & & \\
\hline
\end{tabular}

heterotrophic denitrification and nitrate-based heterotrophic denitrification (in presence of lactose) were as follows:

\section{ANAMMOX}

$$
\begin{aligned}
& \mathrm{NH}_{4}^{+}+\mathrm{NO}_{2}^{-} \rightarrow \mathrm{N}_{2}+2 \mathrm{H}_{2} \mathrm{O} \\
& \Delta_{\mathrm{r}} \mathrm{G}_{\mathrm{m}}^{\theta}=-357.79 \mathrm{~kJ} / \mathrm{mol} \mathrm{NO}_{2}^{-}
\end{aligned}
$$

Denitrification

$$
\begin{aligned}
& 1 / 16 \mathrm{C}_{12} \mathrm{H}_{22} \mathrm{O}_{11}+1 / 16 \mathrm{H}_{2} \mathrm{O}+\mathrm{NO}_{2}^{-}+\mathrm{H}^{+} \rightarrow 1 / 2 \mathrm{~N}_{2}(\mathrm{~g}) \\
& +3 / 4 \mathrm{CO}_{2}(\mathrm{~g})+5 / 4 \mathrm{H}_{2} \mathrm{O} \\
& \Delta_{\mathrm{r}} \mathrm{G}_{\mathrm{m}}^{\theta}=-406.03 \mathrm{~kJ} / \mathrm{molNO}_{2}^{-}
\end{aligned}
$$

$$
\begin{aligned}
& \mathrm{C}_{12} \mathrm{H}_{22} \mathrm{O}_{11}+\mathrm{H}_{2} \mathrm{O}+16 \mathrm{NO}_{2}^{-}+16 \mathrm{H}^{+} \rightarrow 8 \mathrm{~N}_{2}(\mathrm{~g}) \\
& \quad+12 \mathrm{CO}_{2}(\mathrm{~g})+20 \mathrm{H}_{2} \mathrm{O} \\
& \Delta_{\mathrm{r}} \mathrm{G}_{\mathrm{m}}^{\theta}=-6496.48 \mathrm{~kJ} / \mathrm{mol} \mathrm{C}_{12} \mathrm{H}_{22} \mathrm{O}_{11}
\end{aligned}
$$

$$
\begin{aligned}
& \mathrm{C}_{12} \mathrm{H}_{22} \mathrm{O}_{11}+48 / 5 \mathrm{NO}_{3}^{-}+48 / 5 \mathrm{H}^{+} \rightarrow 24 / 5 \mathrm{~N}_{2}(\mathrm{~g}) \\
& \quad+12 \mathrm{CO}_{2}(\mathrm{~g})+79 / 5 \mathrm{H}_{2} \mathrm{O} \\
& \Delta_{\mathrm{r}} \mathrm{G}_{\mathrm{m}}^{\theta}=-5212.9 \mathrm{~kJ} / \mathrm{mol} \mathrm{C}_{12} \mathrm{H}_{22} \mathrm{O}_{11}
\end{aligned}
$$

$\Delta_{\mathrm{r}} \mathrm{G}_{\mathrm{m}}^{\theta}$ was described as the Gibbs free energy in standard state (temperature was $298.15 \mathrm{~K}$ and atmospheric pressure was $101.325 \mathrm{kPa}$ ). Among them, $\mathrm{NO}_{2}{ }^{-}-\mathrm{N}$ was the common substrate for both ANAMMOX and nitrite-based heterotrophic denitrification. Likewise, the addition of OM might have provoked the competition between nitrite-based heterotrophic denitrification and nitrate-based heterotrophic denitrification. Thus, the competition for substrate might have existed among these three bio-reactions.

As thermodynamic analysis showed above, for nitrite competition, $\Delta_{\mathrm{r}} \mathrm{G}_{\mathrm{m}}^{\theta}$ of ANAMMOX reaction $\left(-357.79 \mathrm{~kJ} / \mathrm{mol} \mathrm{NO}_{2}{ }^{-}\right)$is higher than that of nitritebased heterotrophic denitrification $(-406.03 \mathrm{~kJ} /$ mol $\mathrm{NO}_{2}{ }^{-}$). However, it is undeniable that AAOB is more likely to receive $\mathrm{NO}_{2}{ }^{-} \mathrm{N}$ at the beginning of dosing lactose where the amount of HDB was still low (Tang et al. 2013) which can be revealed by the promotion of low COD concentration on ANAMMOX reaction. However, based on the thermodynamic analysis of $\Delta_{\mathrm{r}} \mathrm{G}_{\mathrm{m}}^{\theta}$, at high COD of lactose, the nitritebased heterotrophic denitrification occurs more easily than ANAMMOX reaction which is in line with the results revealed above. 
Table 5 Simulated values through the modified Boltzmann model

\begin{tabular}{|c|c|c|c|c|c|c|c|c|c|c|}
\hline Lactose & 0 & 40 & 80 & 120 & 160 & 200 & 240 & 280 & 320 & 360 \\
\hline $\mathrm{NRE}_{\max }(\%)$ & 83.68 & 84.81 & 86.90 & 89.69 & 93.22 & 94.21 & 94.05 & 94.84 & 92.72 & 90.34 \\
\hline $\mathrm{NRE}_{\min }(\%)$ & -8.83 & -9.67 & -9.73 & -8.86 & -12.04 & -10.74 & -8.78 & -11.80 & -10.96 & -11.15 \\
\hline $\mathrm{t}_{\mathrm{c}}$ & 2.43 & 2.39 & 2.37 & 2.36 & 2.28 & 2.29 & 2.40 & 2.39 & 2.32 & 2.17 \\
\hline$t_{d}$ & 0.99 & 0.95 & 0.99 & 1.05 & 1.04 & 1.00 & 0.99 & 1.08 & 1.04 & 1.02 \\
\hline $\mathrm{R}^{2}$ & 0.9978 & 0.9966 & 0.9983 & 0.9990 & 0.9986 & 0.9986 & 0.9990 & 0.9991 & 0.9985 & 0.9966 \\
\hline Peptone & 0 & 40 & 80 & 120 & 160 & 200 & 240 & & & \\
\hline $\mathrm{NRE}_{\max }(\%)$ & 83.68 & 83.41 & 85.27 & 86.76 & 87.71 & 84.11 & 85.95 & & & \\
\hline $\mathrm{NRE}_{\min }(\%)$ & -8.83 & -11.43 & -7.82 & -6.64 & -4.86 & -11.26 & -18.81 & & & \\
\hline$t_{c}$ & 2.43 & 2.02 & 1.98 & 2.01 & 2.29 & 1.85 & 2.27 & & & \\
\hline$t_{d}$ & 0.99 & 0.93 & 0.76 & 0.70 & 0.72 & 0.89 & 1.28 & & & \\
\hline $\mathrm{R}^{2}$ & 0.9978 & 0.9961 & 0.9979 & 0.9985 & 0.9991 & 0.9985 & 0.9941 & & & \\
\hline $\begin{array}{l}\text { Sodium potassium } \\
\text { tartrate }\end{array}$ & 0 & 40 & 80 & 120 & 160 & 200 & 240 & & & \\
\hline $\mathrm{NRE}_{\max }(\%)$ & 83.68 & 83.90 & 85.39 & 87.22 & 84.55 & 82.55 & 80.51 & & & \\
\hline $\mathrm{NRE}_{\min }(\%)$ & -8.83 & -10.40 & -10.54 & -5.29 & -5.72 & -6.28 & -14.20 & & & \\
\hline$t_{c}$ & 2.43 & 2.06 & 2.19 & 2.25 & 2.14 & 1.97 & 1.90 & & & \\
\hline$t_{d}$ & 0.99 & 0.94 & 0.95 & 0.82 & 0.71 & 0.86 & 1.02 & & & \\
\hline $\mathrm{R}^{2}$ & 0.9978 & 0.9987 & 0.9973 & 0.9978 & 0.9969 & 0.9961 & 0.9981 & & & \\
\hline Sodium succinate & 0 & 40 & 80 & 120 & 160 & 200 & 240 & & & \\
\hline $\mathrm{NRE}_{\max }(\%)$ & 83.68 & 83.00 & 83.94 & 84.89 & 83.09 & 81.13 & 77.16 & & & \\
\hline $\mathrm{NRE}_{\min }(\%)$ & -8.83 & -10.82 & -11.65 & -21.78 & -17.66 & -11.89 & -13.92 & & & \\
\hline $\mathrm{t}_{\mathrm{c}}$ & 2.43 & 2.27 & 2.15 & 1.82 & 1.81 & 1.87 & 1.86 & & & \\
\hline$t_{d}$ & 0.99 & 1.02 & 1.02 & 1.25 & 1.06 & 0.93 & 1.03 & & & \\
\hline $\mathrm{R}^{2}$ & 0.9978 & 0.9979 & 0.9988 & 0.9950 & 0.9965 & 0.9984 & 0.9991 & & & \\
\hline
\end{tabular}

Similarly, thermodynamic analyses suggested that the $\Delta_{\mathrm{r}} \mathrm{G}_{\mathrm{m}}^{\theta}$ of nitrate-based heterotrophic denitrification $\left(-5212.9 \mathrm{~kJ} / \mathrm{mol} \mathrm{C}_{12} \mathrm{H}_{22} \mathrm{O}_{11}\right)$ is higher than nitritebased heterotrophic denitrification $(-6496.48 \mathrm{~kJ} / \mathrm{mol}$ $\mathrm{C}_{12} \mathrm{H}_{22} \mathrm{O}_{11}$ ). Organic matter was initially consumed by nitrite oxidizing bacteria. Then it was consumed by nitrate oxidizing bacteria. This could explain that adding extra $\mathrm{NO}_{2}{ }^{-}-\mathrm{N}$ benefited ANAMMOX reaction in presence of $\mathrm{OM}$.

\section{Conclusions}

SBRs were used to test nitrogen removal performance of ANAMMOX in presence of different OMs. Independent of OM species, ANAMMOX reaction was promoted when COD was lower than $80 \mathrm{mg} / \mathrm{L}$. However, SAA decreased with increasing organic matter content. The values of ARE decreased to $80 \%$ when COD of sodium succinate, sodium potassium tartrate, peptone and lactose were 192.5, 210, 225 and $325 \mathrm{mg} / \mathrm{L}$, respectively. The stoichiometry ratio resulting from different $\mathrm{OM}$ differed largely and $\mathrm{R}_{1}$ could be as an indicator for OM inhibition. When COD concentration was $240 \mathrm{mg} / \mathrm{L}$, the loss of SAA resulting from lactose, peptone, sodium potassium tartrate and sodium succinate were $28,36,50$ and $55 \%$, respectively. Sodium succinate had the highest inhibitory effect on SAA. The competition for $\mathrm{NO}_{2}{ }^{-} \mathrm{N}$ and living space between AAOB and HDB could weaken ANAMMOX process. In wastewater engineering, adding extra $\mathrm{NO}_{2}{ }^{-}-\mathrm{N}$ benefited ANAMMOX reaction in presence of OM. When ANAMMOX process was used to treat wastewater containing OM, the modified Logistic model could be employed to predict the $\mathrm{NRE}_{\max }$ very well.

Acknowledgements The work was financially supported by Shandong Provincial Natural Science Foundation (BS2015HZ007), Shandong Province Higher Educational Science and Technology 
Program (J15LC61) and Key Lab of Marine Bioactive Substances and Modern Analytical Technique (MBSMAT-2015-01).

\section{References}

Anjali G, Sabumon PC (2014) Unprecedented development of anammox in presence of organic carbon using seed biomass from a tannery Common Effluent Treatment Plant (CETP). Bioresour Technol 153(2):30-38

APHA (1998) Standard methods for the examination of water and wastewater, 20th edn. American Public Health Association, Washington, DC

Chamchoi N, Nitisoravut S, Schmidt JE (2008) Inactivation of ANAMMOX communities under concurrent operation of anaerobic ammonium oxidation (ANAMMOX) and denitrification. Bioresour Technol 99(9):3331-3336

Dalsgaard T, Thamdrup B (2002) Factors controlling anaerobic ammonium oxidation with nitrite in marine sediments. Appl Environ Microbiol 68(8):3802-3808

Dapena-Mora A, Campos IFL (2007) Evaluation of activity and inhibition effects on ANAMMOX process by batch tests based on the nitrogen gas production. Enzyme Microb Technol 40(4):859-865

Dosta J, Fernández I, Vázquez-Padín JR, Mosquera-Corral A, Campos JL, Mata-Álvarez J, Méndez R (2008) Short- and long-term effects of temperature on the ANAMMOX process. J Hazard Mater 154(1-3):688-693

Fernández I, Mosquera-Corral A, Campos JL, Méndez R (2009) Operation of an ANAMMOX SBR in the presence of two broad-spectrum antibiotics. Process Biochem 44(4): 494-498

Guven D, Dapena A, Kartal B, Schmid MC, Maas B, van de PasSchoonen K, Sozen S, Mendez R, Op den Camp HJ, Jetten MS, Strous M, Schmidt I (2005) Propionate oxidation by and methanol inhibition of anaerobic ammonium-oxidizing bacteria. Appl Environ Microbiol 71(2):1066-1071

Isaka K, Suwa Y, Kimura Y, Yamagishi T, Sumino T, Tsuneda S (2008) Anaerobic ammonium oxidation (ANAMMOX) irreversibly inhibited by methanol. Appl Microbiol Biotechnol 81(2):379-385

Jensen MM, Thamdrup B, Dalsgaard T (2007) Effects of specific inhibitors on ANAMMOX and denitrification in marine sediments. Appl Environ Microbiol 73(10): $3151-3158$

Kartal B, Rattray J, van Niftrik LA, van de Vossenberg J, Schmid MC, Webb RI, Schouten S, Fuerst JA, Damste JS, Jetten MS, Strous M (2007) Candidatus "ANAMMOXoglobus propionicus" a new propionate oxidizing species of anaerobic ammonium oxidizing bacteria. Syst Appl Microbiol 30(1):39-49

Kuenen JG (2008) ANAMMOX bacteria: from discovery to application. Nat Rev Microbiol 6(6):320-326

Li J, Qiang Z, Yu D, Wang D, Zhang P, Li Y (2016) Performance and microbial community of simultaneous anammox and denitrification (SAD) process in a sequencing batch reactor. Bioresour Technol 218:1064-1072

Liu C, Zhao D, Yan L, Wang A, Gu Y, Lee DJ (2015) Elemental sulfur formation and nitrogen removal from wastewaters by autotrophic denitrifiers and ANAMMOX bacteria. Bioresour Technol 191:332-336

Ma B, Wang S, Cao S, Miao Y, Jia F, Du R, Peng Y (2016) Biological nitrogen removal from sewage via ANAMMOX: recent advances. Bioresour Technol 200:981-990

Molinuevo B, Garcia MC, Karakashev D, Angelidaki I (2009) ANAMMOX for ammonia removal from pig manure effluents: effect of organic matter content on process performance. Bioresour Technol 100(7):2171-2175

Ni SQ, Ni JY, Hu DL, Sung S (2012) Effect of organic matter on the performance of granular ANAMMOX process. Bioresour Technol 110(110):701-705

Okamoto H, Kawamura K, Nishiyama T, Fujii T, Furukawa K (2012) Development of a fixed-bed anammox reactor with high treatment potential. Biodegradation 24(1):99-110

Oshiki M, Shimokawa M, Fujii N, Satoh H, Okabe S (2011) Physiological characteristics of the anaerobic ammoniumoxidizing bacterium 'Candidatus Brocadia sinica'. Microbiology 157(6):1706-1713

Qiao S, Kawakubo Y, Cheng Y, Nishiyama T, Fujii T, Furukawa $\mathrm{K}$ (2009) Identification of bacteria coexisting with anammox bacteria in an upflow column type reactor. Biodegradation 20(1):117-124

Qiao S, Yin X, Zhou J, Furukawa K (2014) Inhibition and recovery of continuous electric field application on the activity of anammox biomass. Biodegradation 25(4):505-513

Regmi P, Holgate B, Fredericks D, Miller MW, Wett B, Murthy S, Bott CB (2015) Optimization of a mainstream nitritation-denitritation process and ANAMMOX polishing. Water Sci Technol 72(4):632-642

Strous M, Heijnen JJ, Kuenen JG, Jetten MSM (1998) The sequencing batch reactor as a powerful tool for the study of slowly growing anaerobic ammonium-oxidizing microorganisms. Appl Microbiol Biotechnol 50(5):589-596

Sun W, Banihani Q, Sierra-Alvarez R, Field JA (2011) Stoichiometric and molecular evidence for the enrichment of anaerobic ammonium oxidizing bacteria from wastewater treatment plant sludge samples. Chemosphere 84(9): 1262-1269

Tang CJ, Zheng P, Wang CH, Mahmood Q (2010) Suppression of anaerobic ammonium oxidizers under high organic content in high-rate ANAMMOX UASB reactor. Bioresour Technol 101(6): 1762-1768

Tang CJ, Ping Z, Chai LY, Min XB (2013) Thermodynamic and kinetic investigation of anaerobic bioprocesses on ANAMMOX under high organic conditions. Chem Eng J 230(16):149-157

Toh SK, Webb RI, Ashbolt NJ (2002) Enrichment of autotrophic anaerobic ammonium-oxidizing consortia from various wastewaters. Microb Ecol 43(43):154-167

Tomar S, Gupta SK, Mishra BK (2015) A novel strategy for simultaneous removal of nitrogen and organic matter using anaerobic granular sludge in ANAMMOX hybrid reactor. Bioresour Technol 197:171-177

van de Graaf AA, Mulder A, de Bruijn P, Jetten MS, Robertson LA, Kuenen JG (1995) Anaerobic oxidation of ammonium is a biologically mediated process. Appl Environ Microb 61(4):1246-1251

van de Graaf AA, de Bruijn P, Robertson LA, Jetten MSM, Kuenen JG (1996) Autotrophic growth of anaerobic 
ammonium-oxidizing micro-organisms in a fluidized bed reactor. Microbiology 142(8):2187-2196

Vlaeminck SE, Terada A, Smets BF, De Clippeleir H, Schaubroeck T, Bolca S, Demeestere L, Mast J, Boon N, Carballa M, Verstraete W (2010) Aggregate size and architecture determine microbial activity balance for one-stage partial nitritation and ANAMMOX. Appl Environ Microb 76(3):900-909

Wang JL, Wan W (2009) Kinetic models for fermentative hydrogen production: a review. Int J Hydrogen Energy 34(8):3313-3323

Xu ZY, Zeng GM, Yang ZH, Xiao Y, Cao M, Sun HS, Ji LL, Chen Y (2009) Biological treatment of landfill leachate with the integration of partial nitrification, anaerobic ammonium oxidation and heterotrophic denitrification. Bioresour Technol 101(1):79-86
Yamamoto T, Takaki K, Koyama T, Furukawa K (2008) Longterm stability of partial nitritation of swine wastewater digester liquor and its subsequent treatment by ANAMMOX. Bioresour Technol 99(14):6419-6425

Yang GF, Jin RC (2013) Reactivation of effluent granular sludge from a high-rate ANAMMOX reactor after storage. Biodegradation 24(1):13-32

Yuan L, Huang Z, Ruan W, Ren H, Zhao M (2015) ANAMMOX performance, granulation, and microbial response under COD disturbance. J Chem Technol Biotechnol 90:139-148

Zwietering M, Jongenburger I, Rombouts FM, van't Riet K (1990) Modeling of the bacterial growth curve. Appl Environ Microbiol 56(6):1875-1881 